\title{
Evaluation of Bureaucracy Reform Based on Integrity For Corruption Prevention
}

\author{
${ }^{1 \text { st }}$ Dita Febrina ${ }^{1},{ }^{2 n d}$ Syamsir $^{2}$ \\ \{ditafebrinasip@gmail.com ${ }^{1}$, syamsirsaili@yahoo.com $\left.{ }^{2}\right\}$ \\ ${ }^{1,2}$ Faculty of Social Sciences, Universitas Negeri Padang, Padang, Indonesia
}

\begin{abstract}
Bureaucracy reform through presidential regulation no. 81 the year 2010 concerning the grand design of bureaucracy reforms 2010-2025 became a reference for the ministry, institutions and local government in reforming the bureaucracy to achieve good governance. The purpose of this study to evaluate the implementation of government bureaucracy reform based on integrity in efforts to prevent corruption by upholding professionalism, with adaptive characteristics, integrity, high performance, free and clear of corruption, collusion and nepotism, capable of serving the public, neutral, prosperous, dedicated and uphold the basic values and code of ethics of the state apparatus. The research method in this article is a qualitative method with a descriptive approach. The finding of this research indicated that integrity-based implementation of bureaucratic reform in sawahlunto was not run optimally, so it needs to be repaired in several aspects. The results of this study implied that the application of the principles of bureaucratic reform still requires more careful preparation and commitment from the bureaucratic leaders to implement it wholeheartedly.
\end{abstract}

Keywords: performance, integrity, and bureaucracy reforms

\section{Introduction}

The government bureaucracy holds the role of principal, even a singular role in the development of a country. Bureaucrats as the organizer of the State must be able to meet the needs of society to order, justice and service to the community can be achieved. Public service to the community is deemed to be efficient if the public has a guarantee. Quality of service must comply with the standard components of service provided for in Article 21 of Law No. 25 of 2009 on the public service so that people can get top priority in handling the improvement of service quality of care. The change of paradigm from centralized towards the decentralized government that mark with the regional autonomy policy brings new nuances in the administration of local governments to empower the community and the region's independence. With paradigm change is at once characterizes the change in volume or workload of local governments to accommodate all matters submitted later will be contained in the structure of regional organizations. The political system was put bureaucracy as the central control of society. Bureaucracy is the institution of public policy implementation. 
Studies on the bureaucracy is a complex matter as it relates to various aspects, such as institutional, human resources, as well as systems and procedures are created and run by the bureaucracy, as well as aspects of the renewal of bureaucracy called the reform of the bureaucracy (Prasojo \& Kurniawan: 2008)[1]. Reform comes from a foreign language "Reformation" (English) or reformative (Netherlands). The basic word "Reformation" is derived from the word reform means reshaping. Reform comes from the word meaning form shape or form (Frinces, 2008: 21)[2]. Reform is a process of systematic effort, integrated, and comprehensive, intended to realize good governance (good governance). This system allows the mechanism of state government implementation of effective and efficient with the constructive synergy between government, private sector, and communities. The ruling government's political will can be used as benchmarks to review the degree of seriousness in carrying out the reform of the bureaucracy (Sedarmayanti: 2009)[3]. In that context, the country established a system of administration that aims to serve the interests of the people who called the bureaucracy. Bureaucratic reform implemented to improve governance better and hope for policymakers as well as anti-corruption activists in promoting the implementation of national development which is clean of corruption, collusion and nepotism[4].

Etymologically, the word corruption (corruption) has equivalent Latin word "corrupt" or "corrupter" means damaging, destroying, rot, and shattered (Skeat 1888, 136; Klein, 1971, 169)[5]. This meaning is consistent with the explanation of Aristotle (2001) in his work De Generatione et Corruption that corruption (corruption), as opposed to the formation/generation (generation), refers to something that ceases to be, degraded, or perish[6]. In a human being, corruption means the deterioration of the tendency to behave from what was supposed to be human behavior. Whereas in the context of the government of a country, corruption means the deterioration that systemic nature of the practices and commitments that make up a healthy governance system (Buchanan 2004)[7]. The meaning of such corruption more emphasis overview corruption as a systemic phenomenon from the perspective of something corrupt. The problem is, the picture of corruption as a systemic phenomenon tends to overestimate the role of the common good (common good) and tend to overlook the possibility that a single action (non-systemic) could corrupt the same destructive with systemic corruption.

Another alternative meaning of corruption is from the viewpoint of a person or group of people who corrupt. Picture highlighted corruption in the form of a single rational action that can be categorized as corruption. Euben (1989) describes corruption as a single action like that with the bases on the assumption that every person is a selfish individual who only cares about their interests[8]. Euben assumptions referring to human nature egoistic illustrated Hobbes (1651) in his work Leviathan that man one more dangerous to humans but that any human can secure the existence and fulfill their interests through mutual agreement embodied in the form of state power[9]. So according to Euben (1989), holders of public power (the State) who obtain legitimacy from all individuals (the result of the collective agreement) are required to exercise their power by standards set in the interests of all individuals (public interests) [8].

Theoretically, the reform (Poltak et al., 2011: 25) is a change in which the change is limited while the breadth of the changes involves the entire community. As changes are limited but the whole community involved, the reform also implies a realignment of public buildings, including the ideals, institutions, and channels that normally reach their goals. Reform gives hope to the public service that is more fair and equitable[10]. Hope thus associated with the strengthening of public control and the contribution of the community in governance. Surbakti (2010) said, possessed great authority bureaucrats so that almost all aspects of society dealt with the bureaucracy. The authority is too big, eventually, even accentuate the role of bureaucracy as a policymaker rather than implementing policies, is more controlled than serving the public. 
Finally, it's natural then bureaucracy considered the source of the problem or a burden to society rather than a source of solutions to problems faced by the community. The phenomenon was due to bureaucratic tradition established more as a tool to control public authorities and its resources. In other words, more bureaucracy acts as Prada civil rather than the civil service[11].

Bureaucratic reforms to restructure the system of government administration, especially concerning the institutional aspects (organization), management (business process) and human resources personnel (Yusriadi, 2018). Structuring the bureaucracy becomes the main agenda because this is what determines the quality bureaucrat various activities organized by the public sector. The long-term development plan 2005-2025 mandates that the utilization of state apparatus is done through bureaucratic reform. Bureaucracy and corruption are the two things are closely related, especially in the implementation of the tasks of the bureaucrats. Therefore, to provide clearer, specific, and measurable directions, the Bureaucratic Reform program was developed through Presidential Regulation Number 81 the Year 2010 concerning the Grand Design of the 2010-2025 Bureaucracy Reform which will become a reference for Ministries, Institutions and Local Governments in implementing bureaucratic reforms. to realize good governance through eight areas of change that must be made[12].

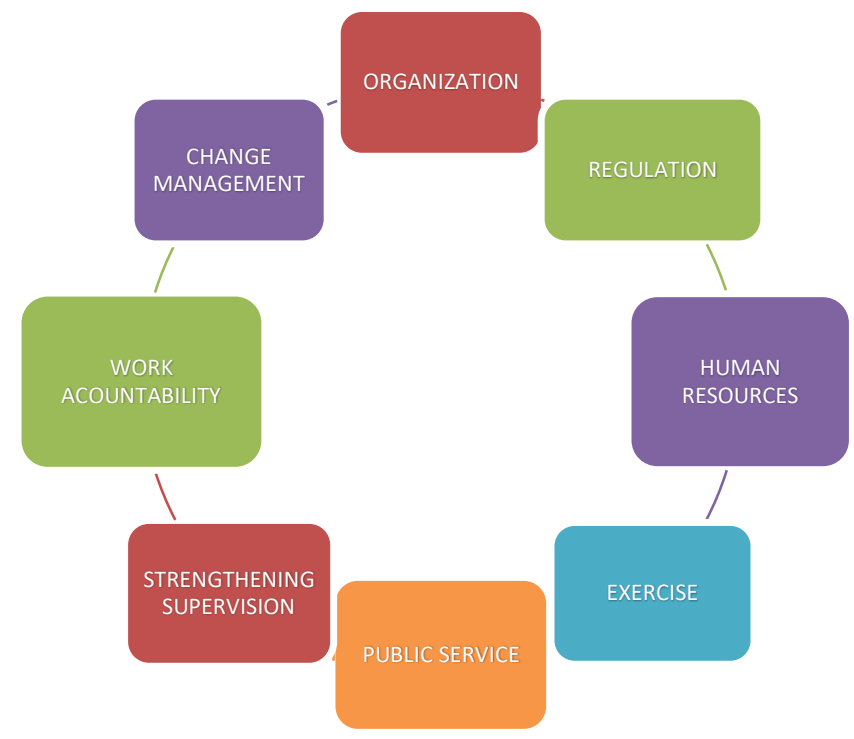

Figure 1. Changes in Area Eight Reforms

The discussions that affect the way of thinking to reduce corruption in Indonesia mainly focused on the eradication of corruption. To prevent corruption in general, three approaches should be done, namely: 1) a structural systematic manner, usually by increased supervision and perfecting the system of public management. 2.) how abolitionists conducted by the enforcement of punishment and sanction corrupt as severe and 3.) how moralistic conducted concerning human moral factor (Purwanto, et al: 2005)[13]. Corruption more easily found in various areas of life, especially the bureaucracy, first because of the weakening of social values, personal interests become more important than the public interest, and the ownership of objects individually into a personal ethic that underlies social behavior most people. Secondly, there is no transparency and accountability of the public integrity system. The bureaucracy of public services can be used by public officials to pursue personal political ambitions, solely, for the promotion and advancement. 
While the quality and quantity of public servants is not a priority and the main orientation. In simple terms, Corruption is the abuse of power and trust for personal gain. Because of the corruption understood in the context of the behavior of public sector officials, politicians, civil servants who have the power and authority to enrich themselves, or with people close to them (Pope 2003: 2)[14]. Seeing complicated and systemic corruption networks that exist today, it would require a joint effort both that are local, national, and international levels. Including how to change the culture of public officials who asked to be served, not to serve the community, as stated by JS Mill, that essence and meaning of bureaucracy is a job running a government by the people who govern professional (Albrow, 2005: 8)[15]. Improvements in the state bureaucracy can not be implemented partially. Often the failure of bureaucracy in carrying out its functions precisely caused by internal factors. Lack of integrity and lack of professionalism of the leadership of the bureaucracy in carrying out its duties and the lack of legislation regarding accountability of bureaucracy remains a major obstacle. Rampant corruption is a central issue for the low performance of the bureaucracy. Improvement of law and justice is also not as reliable as the recovery strategy and the public trust outsiders against Indonesia's bureaucracy(Irawati,2013)[16].

Entering the reform era, the Indonesian government challenges in realizing good governance is to overcome the crisis of public confidence in the public service. The crisis arising from bureaucratic buildings during the period of the new order is even sparked protests at the central and local levels (Dwiyanto et al., 2002; Thoha, 2012)[17][18]. As a result of the behavior of bureaucrats tend not to support public services has led to the initial purpose of bureaucrats in delivering public services to shift toward pragmatism and degrade the integrity and quality (Horhoruw et al., 2012)[19]. Ideally, public service delivery by government officials, public service providers must be conducted in the absence of corruption, collusion and nepotism (KKN) (Girindrawardana, 2002)[20]. Furthermore, a survey reported that the index of public service integrity is ranked 70 of 109 countries, even below neighboring countries such as East Timor, the Philippines, Malaysia, and Thailand. In fact, in the survey, administrative services component being the worst with the ranks 97 (Mungiu Pippidi et al., 2017)[21]. It signifies the need for improvement, especially in terms of public administration so that public service becomes more optimal. Hence the need to accelerate the achievement of good governance through the implementation of bureaucratic reform in all ministries, institutions and local governments to prevent corruption in the various public sphere. Grand Design and the Road Map for Reforms also mentioned that the vision Reform is to create a world-class administration. With this vision Reforms various programs aimed at creating a professional administration and high integrity that delivers excellent service to the public and management of democratic governance. The purpose of bureaucratic reform is to create a professional government bureaucracy, with adaptive characteristics, integrity, high performance, free and clear of corruption, collusion and nepotism, capable of serving the public, neutral, prosperous, dedicated and hold fast to the values of the base and a code of ethics apparatus state.

The big challenge faced by the bureaucracy is how they can implement activities efficiently and effectively (Cordela, A., \& Tempini, N., 2015)[22]. Therefore, during this bureaucracy in identical with the performance of a convoluted structure that is too large, filled with corruption, collusion, and nepotism, and there is no definite standard. Some problems such bureaucracy is an obstacle that is very meaningful in the context of the embodiment of bureaucratic reform. Government Sawahlunto as state institutions that carry out business in the Local Government directed to improve the capacity of the bureaucracy. Where in the context must be able to produce bureaucratic institutions that can accommodate the demands of society? 
Governmental organizations in the achievement of organizational goals can be accomplished if the employees who are in the organization can work optimally.

As well as the organization's goals will be achieved through a positive performance of its employees, otherwise, the organization will encounter obstacles in achieving the goals when Parta employee job performance is not effective in the sense of meeting the demands of the job desired by the organization (Ahmad, 2009)[23]. In managing an organization's human resource needs that have good integrity. Integrity is one of the characters that make up the Strength of courage. Integrity as a character drawn up by virtue honesty and authenticity. So, integrity is not just honesty, even though when hearing the expression 'individual with integrity' most of the time think of someone honest (Masitah, 2012)[24].

The theory of integrity developed as a result of dissatisfaction with the theory of moral development Kohlberg less provide for the self role in accepting moral values (Blasi, 2004)[25]. Individuals have an intuition of what is right and wrong, but often do not realize the reason and trouble to explain his actions. The provision of public services by government officials still found weaknesses and gradually so the impact declining quality of public services to the community. The weakness was indicated there are symptoms, not optimal employee integrity. Integrity is an uncompromising adherence to a code of moral values, and avoid deception, expediency, artificiality, or shallowness of any kind. Government Sawahlunto has the role and function of strategic planning of its existence within the framework of achieving the vision of the government. Position, duties, and functions that are ideally required to always be able to show high performance. Based on field observations in which the author directly observe, interact and based on the evaluation of bureaucratic reform in 2018 of the Ministry of Administrative Reform and Bureaucratic Reform of the Republic of Indonesia to the environment Sawahlunto, there is not yet optimal symptom-based integrity of bureaucratic reform. The data gave by the Ministry based on a survey of bureaucratic reform based integrity in Sawahlunto. The integrity index above illustrates Environmental employee perceptions in Sawahlunto to the quality of the bureaucracy reform based on prevailing internal integrity[26]. Based on the survey that was conducted internally by Kemenpan \& Reforms to demonstrate the integrity of 2.95 index score of $0-4$, with details as follows:

Table 1. Outcomes Integrity Index

\begin{tabular}{|l|l|l|}
\hline No. & Component & $\mathbf{2 0 1 8}$ Index \\
\hline 1. & Organizational culture and system of Anti-Corruption & 2.87 \\
\hline 2. & Related Integrity of HR management & 2.89 \\
\hline 3 & Related integrity of budget management & 3.19 \\
\hline 4. & Integrity superior orders conformity with rules and norms & 2.88 \\
\hline Integrity Index & 2,95 \\
\hline
\end{tabular}

The table above shows the achievement is below the score is 2.95 . While the Ideal Integrity Index, which is 3.90, as stipulated in the Regulation of the Minister of Administrative Reform and Bureaucratic Reform No. 52 of 2014. As such, they must do repairs and evaluation, or in other words, some things should be fixed within the bureaucracy reform based integrity in Sawahlunto. The results of the research above observations were confirmed by interviews with the Head researcher. Public Administration and Personnel Division of General Regional Secretariat of Sawahlunto Adhe Rusrita on December 18, 2019, at 10:00 pm that integrity-based bureaucracy reform is still seen not optimal value integrity. This is evident from employees who enter and leave work not following a predetermined schedule is a form of integrity is not optimal, an employee who can not master the work, employees often make the mistake of 
repeatedly so the impact of delay in the work process. It is characterized by services, not by the demands Public.

Ineffective use of services provided by the state apparatus due to the low value of the employee-owned integrity so that employees in acts inconsistent and incompatible with the values and policies organization and code of ethics nature take its course. Also, visible from employees who enter and leave work not by a predetermined schedule, employees who can not master the job. In the administration cycle, the recovery will be done if it had carried out evaluation activities. Through the evaluation, constraints in the implementation of the program can be measured. The success of a government program is not only determined by the quality of planning and implementation but also how the program can be evaluated regularly. Evaluation in view critical in driving the success of the planning and is an indicator of the success of a program (Conyers, 1991: 272)[27]. Besides the evaluation of not only the formulation of a program but also the feedback to formulate future strategies. Isaac and Michael (1983: 8-9) define evaluation as a process for assessing the performance of a particular behavior or formulated in goal.

Likewise proposed by Hammond in Isaac and Michael (1983: 8-9) that the evaluation is the process of assessing the effectiveness of the latest and innovative program by comparing data regarding the behavior with the expected objectives achieved[28]. Because in essence the evaluation of the integrity-based bureaucracy reform is done to see the extent of bureaucratic reforms have managed to achieve a predetermined goal. Without evaluation, integrity-based bureaucracy reform can not be viewed as effective. Through the evaluation, it will produce data and information and recommendations for policymakers to decide improvement and refinement of execution being carried out so that the bureaucracy reform based on integrity can run as expected. Reforms should continue to run using a holistic approach, consistent and ongoing. Progress and success of the reform of the bureaucracy into something important to note as the basis for follow-up and guarantee a sustainable reform process(Dima, 2016)[29]. Based on the explanation above, the writer interested to do more research on "Evaluation of the implementation of integrity-based bureaucracy reform in efforts to prevent corruption in Sawahlunto West Sumatera".

There were so many studies found that integrity could influence employee performance, including in preventing cooruption behaviour. Rosmi and Syamsir (2020) [30], Tasi and Syamsir (2020) [31], Febrina and Syamsir (2020) [32], and Wahyuni and Syamsir (2020) [33], for instance, in some of their studies among civil servants in Bungo District, Sijunjung Regency, Sawahlunto City, Kerinci Regency, and found that integrity and several other variables significantly influenced employee performance. The other studies also showed the effect of integrity on employee performance, as conducted by: Jayanti and Syamsir (2019) [34], Yolanda and Syamsir (2020) [35], Salwa, Away and Tabrani (2018) [36], Wetik, et al (2018) [37], Aski (2020) [38], and Syamsir and Ali Embi (2020)[39]. All of this studies indicated that integrity had influence on the performance of civil servants in the government institutions.

\section{Methodology}

This study used a qualitative method with a descriptive approach (Arikunto 2010: 176)[40]. According to Creswell (2015: 4) [41], the qualitative research methods to explore and understand the meaning by individuals or groups of people ascribed social or humanitarian issues. Qualitative research is used if the problem is not clear, knowing the hidden meaning, understanding social interaction, develop theory, ensure the correctness of the data, and 
researching the history of development. The implementation of this evaluation will be looking for information within and wide for a complete picture of an object in the evaluation. Research methods used in this study are evaluative studies/evaluations because they want to evaluate activity in one certain unit, in this case, is based on the integrity of bureaucratic reform in efforts to prevent corruption were carried out in Sawahlunto. Descriptive nature that aims to describe and analyze the extent to which the implementation of the reform of the bureaucracy at City Sawahlutno. The research focus is the evaluation of the implementation of bureaucratic reform based Integrity in efforts to prevent corruption in Sawahlunto. Data derived from primary and secondary data that uses data collection techniques using triangulation (Sugiyono, 2011: 226)[42].

\section{Finding And Discussion}

Reform of the bureaucracy can be interpreted as fundamental changes, both ways of thinking, as well as the culture of state administrators of mentality, which is overseeing, control and domination of society (colonial paradigm) which refers to good public services and governance to minimize the occurrence of acts of corruption, collusion, and Nepotism, both the superstructure and infrastructure of state officials and law enforcement. Bureaucratic reform aimed at creating a government bureaucracy that is professional with The characteristics of adaptive, integrity, high-performance, clean and free from corruption, collusion and nepotism, capable of serving the public, neutral, prosperous, dedicated, and uphold the basic values and code of ethics of the state apparatus. Bureaucratic reform targets clean and accountable, effective and efficient that have quality public services. To realize the goals and objectives set out bureaucratic reform in eight areas of change in the bureaucracy[43]. Thus, changes in certain areas within the scope of the bureaucracy is expected to create conditions conducive to support the achievement of bureaucratic reform, as described in the figure below:

Table.2 Eight Areas of the change in bureaucracy reform

\begin{tabular}{|l|l|rl|}
\hline No. & Area Changes & Purpose Of Bureaucracy Reform \\
\hline 1 & Change Management & & $\begin{array}{l}\text { Clean And Non-Government } \\
\text { Corruption, Collusion And Nepotism }\end{array}$ \\
\hline 2 & Strengthening Supervision & & $\begin{array}{l}\text { Effectiveness And Efficiency Of } \\
\text { Government }\end{array}$ \\
\hline 3 & Strengthening Accountability Performance & 3. Improved Quality Policy Decision \\
\hline 4 & Reforming The Organization & Resource Arrangement Apparatus & 4. Improving The Quality Of Public \\
\hline 6 & Reforming The Regulation Legislation &
\end{tabular}

The essence of the changes in the bureaucratic reform is the achievement of bureaucratic reforms such as good governance of Corruption, Collusion and Nepotism, effectiveness and efficiency of government activities, improving the quality of policymaking and improving the quality of public services as well as changes in the mental apparatus. Employees who are professional and integrity can only be established through Reforms. A discussion of the reform of the bureaucracy is only likely to deliver change when touching the fundamental dimensions, namely a paradigm shift both the ideology and values. Mental Revolution brought President 
Joko Widodo to be understood and placed in that context. Fundamental changes that include values, traits, gestures, and all action should be directed to ensure the ideals of living together as would otherwise occur (Prastowo, 2014)[44].

But these changes can not be done only through measures aimed directly at the apparatus, but also must be addressed to the whole system surrounding the apparatus. Currently, bureaucratic reform is no longer just the demands of all elements of society who hoped that bureaucracy and especially the apparatus can be better quality, but the bureaucratic reform is now really become a necessity for the government apparatus. Nevertheless, the change should be restrained, should always be planned direction of change itself. Any changes must be followed so that we can drive the change toward better by national development priorities set out in the Nawa Cita. Eight items of Nawa Cita is Conducting National Character of the Revolution. To make the revolution a national character, the challenge is to make the educational process as a means of formation of character and personality of a mature student with the internalization and integration of character education in the curriculum, the learning system and assessment systems in education. The main challenge faced to strengthen the character and identity of the nation is to improve the community's ability to adopt a global culture that is positive and productive and to increase understanding and awareness of the importance of language, customs, traditions, and values of local wisdom that is positive as the adhesive of national unity. The main idea behind the bureaucratic reform is good governance. To realize these objectives it is done by government management that is necessary to change in earnest and sustained[45].

The government has committed which is quite a serious effort to eradicate corruption, marked by the release of some of the regulations that give legitimacy to measures and anticorruption movement. At least three laws have been established to support this motion, Law No. 31 of 1999 on Corruption Eradication, which was subsequently amended by the Act No. 20 of 2001, Law No. 30 of 2002 on the Corruption Eradication Commission, and Law No. 46 of 2009 on the Corruption Court[46]. Nevertheless, as has been described above, then efforts to create regulatory and law enforcement certainly not enough to root out corruption. Need to change the paradigm of the state apparatus, the bureaucracy, and public governance. In this context, the required reorientation of the bureaucracy to free himself from a service-oriented towards power and waiters for himself. The structure of a dilemma that makes the bureaucracy stuck in the interests of power or which tends to be measured through political measures must be transformed into the other categories in the public service. Measures success purely bureaucratic performance is only measured through procedural accuracy should be developed in the direction oriented measures out (public service).

The position of the bureaucracy would increase if they can put a solid position as a partner for the community. As a partner, the bureaucracy can be a party that is sensitive and responsive to changes in society, so the service aspect in the sense oriented demands of the public wants it to do. However, as a partner, in some cases, it can not be denied the position remains the dominant bureaucracy. This is where the significance of conceptualization Fukuyama in terms of repositioning the country (including the bureaucracy). In his book State Building, Fukuyama stressed the importance of re-conceptualizing the position and role of the state through two main concepts, namely the scope (scope) and capacity (capacity) of the state (Fukuyama, 2004)[47].

Fukuyama explains the relation between the (scope) and capacity (capacity) will put a country in one of four quadrants as in Figure 1. A strong or can be successful is a country that has a strong capacity, either with functions that lot or a little. But the need to emphasize that state capacity is the extent to which countries can function properly. Strong state capacity is not necessarily in the sense set widely but rather the quality and capacity of the 
country that produce prosperity for the people. If we draw Fukuyama's thesis into the current situation of the Indonesian state may be seen from the role of the state through a very dominant bureaucracy, it is necessary to reposition themselves bureaucracy itself.

The implementation of bureaucratic reform means government bureaucracy can work well according to the principles of modern management is getting better in the construction and service to the community that is the main task of the bureaucracy. On the other hand, the internal improvement efforts continue to be pursued with the development capacity and competence of the organizers both in quality and quantity. So expect in the future produce clean bureaucracy, accountable, effective and efficient and have quality public services to realize the performancebased government. Changes in the area of integrated through the tasks and functions in Sawahlunto to create conditions conducive to the achievement of goals and objectives to support bureaucratic reform. For the implementation of bureaucratic reform can walk in the direction that has been set, it needs to be evaluated periodically to determine the extent of the progress of the results of its implementation. Besides, the evaluation is also intended to provide input in drafting an action plan for the sustainable improvement of bureaucratic reform or the period of the next year. An assessment of each program in the lever component (process) and bureaucratic reform targets measured through indicators that were seen to represent the program. To assess the indicators are expected to describe the achievement of the efforts that impact on the achievement of targets. Achievement of the objectives of reform bureaucracy one of them must be based on integrity for the prevention of corruption[48].

Quah (1992) presents three (3) models of combating corruption bureaucratic reform efforts that have been practiced in some countries and succeeded in reducing corruption in these countries, namely: 1.Anti-Corruption Legislation with no Independent Agency. Practiced si Mongolia. 2.Anti-Corruption Legislation with Several Agencies. This model is practiced in India and the Philippines. 3.Anti-Corruption Legislation with an Independent Agency[49]. Quah All three models can help the government to fight corruption. But among the three models, the three models most effective in eradicating corruption. Quah's success in helping the government of Singapore and Hong Kong have been investigated by Volg et al. Volg and comrades even recommend a model Hong Kong as the "Hong Kong SAR as a Model" (Pope, Jeremy, and Frank Volg, 2000)[50]. Then, this model was emulated in Indonesia by the formation of the KPK.

The Corruption Eradication Commission (KPK) as an independent agency that deals specifically with corruption, be a deterrence of corruption. But on the other hand, enforcement efforts will cost quite a bit. Not to mention if calculated from the impact caused to the life of society and the state. As we know the fight against corruption the most inexpensive and effective is the precaution Part I $\mid 15$ (preventive). As anti-corruption education and cultivation of the values of integrity to children from an early age (Nana Puspito T. et al, 2011)[51]. Ashford (2000), for example, make sense of integrity with an emphasis on ensuring the objectivity of how individuals must comply with its commitment to moral obligations. For Ashford, individual self-conception can be developed but should be adapted to the requirements of real moral from outside himself. Such objective integrity of meaning implies that the attributes of integrity can only be granted to individual morality coincides with the donor community attributes. The problem is, the provision of integrity attributes is generally not strictly require the approval of the giver of moral attributes[52]. As indicated by Hooft (2003), we can still respect the person as a person of integrity even if we disagree with certain views on moral issues. Imposing a moral approval giver means degrading attributes of the individual as the subject of mortality.

Thus, the expression of integrity directly opposite to corruption. While the act of directing the functioning of the particularity of integrity for the sake of the common good, corruption directing what should be the common good for the sake of particular interest. While the act of 
integrity promotes or increases the likelihood of the realization of the ideal community, corruption undermines or minimizes the possibility of the realization of the ideal community. Because substantially exact opposite direction, integrity is not only empirically prevent corruption but logically necessary counteracting corruption. This conclusion does not mean that people of integrity tend to overlook the importance of particularity. Related to the importance of particularity, the following three records could perhaps complete the picture of integrity and people of integrity[53].

So for individuals of integrity, the urgency of life-particularity that it has to be maintained (first record), the quality of the particularity that it has to be constantly improved (second record), and the importance of the particularity of its not going to be humbled on the grounds of the common good (the third note ). Meaning not emphasize the integrity of polarization "particularity" versus "the common good (common good)" by positioning one more important than the other, but rather emphasize the functional direction of particularity to the common good (common good). The emphasis on functional directions showed that the expression of integrity is substantially opposite to corruption because corruption pushes what should be the common good (common good) towards particular interests. A good character or a good organizational culture, integrity contains a logical necessity to ward off corruption[54].

Integrity in the context of government and bureaucracy is the use of official power, authority and authorized by public officials for legitimate (justified) according to the law. Integrity is thus self persistence of bureaucratic apparatus and public officials not to solicit or accept anything of. With so, integrity is the antithesis of corruption is the use of power for unauthorized or illegal either by individuals or groups that hold power, authority, and authority. Therefore, the creation and strengthening of the integrity of public officials are one of the most important factors not only in combating corruption but also in administrative reform to the establishment of good governance. Strengthening the integrity of public officials who are in public sector governance and also the authorities on the private sector and society as a whole proved in many countries as one of the effective ways to build attitudes and awareness in the government and the public as a whole to eradicate or at least reduce corruption more effectively. And, further, the existence of such integrity can provide support for the creation of good governance[55].

Evaluation of the implementation of integrity-based bureaucracy reform in efforts to prevent corruption is a systematic assessment conducted to determine the results of the work by the demands and responsibilities, as well as provide guidance Untuk make changes and prevention of corruption. An assessment of bureaucratic reform of integrity can be done by measuring how far achieved integrity index as expected to improve integrity. In this assessment, integrity-based implementation of bureaucratic reform in efforts to prevent corruption in Sawahlunto. The elements are used as a reference in evaluating the ratings are through the achievements of the eight areas of change refers to the purpose of bureaucratic reform based on integrity, where there is the first destination that contains "government free from corruption, collusion, and nepotism". So from the results of the evaluation of the bureaucracy bureaucratic reform to realize a clean, accountable and high-performance, effective and efficiently capable of providing quality public services, not run optimally for Sawahlunto scored 52.22 with the notation "CC" with a value of $50<$ values $>60$. Here are a table index bureaucratic reforms: not run optimally for Sawahlunto scored 52.22 with the notation "CC" with a value of 50 <value> 60. Here are a table index bureaucratic reforms: not run optimally for Sawahlunto scored 52.22 with the notation "CC" with a value of 50 <value> 60. Here are a table index bureaucratic reforms: 
Table 3. Bureaucratic reform index Sawahlunto

\begin{tabular}{|l|l|l|l|}
\hline No. & agency & Value Reforms & Predicate \\
\hline 1 & Padang city & 68.08 & B \\
\hline 2 & West Sumatra Province & 65.63 & B \\
\hline 3 & Payakumbuh & 61.69 & B \\
\hline 4 & Solok & 58.41 & CC \\
\hline 5 & Tanah Datar & 54.74 & CC \\
\hline 6 & Bukittinggi city & 52.80 & CC \\
\hline $\mathbf{7}$ & Sawahlunto & $\mathbf{5 2 . 2 2}$ & CC \\
\hline 8 & Solok District & 52.15 & CC \\
\hline 9 & Padang Pariaman & 51.96 & CC \\
\hline 10 & Padang Panjang & 50.49 & CC \\
\hline 11 & Kota Pariaman & 49.26 & CC \\
\hline
\end{tabular}

The evaluation focused on the efforts undertaken by the Government of Sawahlunto in the implementation of bureaucratic reform. The purpose of evaluation to assess the progress of the implementation of the reform of the bureaucracy to achieve the target. Besides the evaluation is also to suggest improvements to improve the quality of implementation of bureaucratic reform. Conclusions as a result of the evaluation are the following:

Table 4. Index of bureaucratic reform details Sawahlunto the category of "CC"

\begin{tabular}{|l|l|l|l|}
\hline No. & Component Rating & Value Scale & Score \\
\hline A. & components Pegungkit & & \\
\hline 1 & Change management & 5.00 & 1.50 \\
\hline 2 & Structuring of legislation & 5.00 & 1.93 \\
\hline 3 & Structuring and Strengthening Organizations & 6.00 & 2.07 \\
\hline 4 & Structuring the management of & 5.00 & 1.91 \\
\hline 5 & Structuring HR management system & 15,00 & 9.54 \\
\hline 6 & Strengthening accountability & 6.00 & 1.63 \\
\hline 7 & Strengthening supervision & 12.00 & 2,96 \\
\hline 8 & Improving the quality of public services & 6.00 & 3.28 \\
\hline & Total Component Levers A & $\mathbf{6 0 . 0 0}$ & $\mathbf{2 4 . 2 8}$ \\
\hline B & component Results & & \\
\hline 1 & Value accountability for performance & 14,00 & 7.02 \\
\hline 2 & Internal surveys integrity organisms & 6.00 & 3.76 \\
\hline 3 & External survey of perception of corruption & 7.00 & 5.69 \\
\hline 4 & Opinion Audit Board & 3.00 & 3.00 \\
\hline 5 & External Survey of Public Service & 10,00 & 7,93 \\
\hline & Total Component of (B) & $\mathbf{4 0 . 0 0}$ & $\mathbf{2 7 . 4 0}$ \\
\hline & Bureaucratic Reform Index (A + B) & $\mathbf{1 0 0 . 0 0}$ & $\mathbf{5 2 . 2 2}$ \\
\hline
\end{tabular}

Based on the above results, the index of bureaucratic reform and integrity illustrates that the need for change and improvement in all aspects. Thus, there is still room for improvement or in other words there are some things that need to be improved in the implementation of 
integrity-based bureaucracy reform in Sawahlunto City as an effort to prevent corruption. So the governance efforts for the advancement of bureaucratic reform, among others:

1. Optimizing HR management systems, among others, by job competency standards, overall employee assessment and perfecting individual performance measures that refer to organizational performance;

2. Develop and implement policies related to the strengthening of integrity that includes control of gratification, whistle bowling system, the handling of conflicts of interest and SPIP handling of complaints;

3. Gradually internalize the direction of change that is announced to all employees in each regional apparatus to understand the direction of the change and be involved in the change process;

4. Optimizing the role of agents of change with real targets in each work unit;

5. Implementing a system of reward and punishment policy for service delivery and provision of compensation to the recipient of the service when the service received is not standardized;

6. Following up on the results of the survey to the positions and organizational integrity as well as the survey results public services and the perception of corruption. Furthermore, it is expected that the leadership seeks to improve understanding of each employee to the performance to be achieved and to build a culture of excellent service and anti-corruption within the work unit; and

7. Building the integrity of the zone in the device area and Bureaucratic Reform minister under Regulation No.52 / 2014 on guidelines for the development of the integrity of the zone towards the area free from corruption and bureaucracy area clean and serve the government agency.

\section{Conclusion}

Evaluation of the implementation of integrity-based bureaucracy reform in efforts to prevent corruption is a systematic assessment conducted to determine the results of the work by the demands and responsibilities, as well as provide guidance for making changes and prevention of corruption. Assessment of bureaucratic reform of integrity can be done by measuring how far the achievements of the integrity of the index as expected to improve integrity. In this assessment, integrity-based implementation of bureaucratic reform in efforts to prevent corruption in Sawahlunto. The elements are used as a reference in evaluating the ratings are through the achievements of the eight areas of change refers to the purpose of bureaucratic reform based on integrity, where there is the first destination that contains "government free from corruption, collusion, and nepotism". So from the results of the evaluation of the bureaucracy bureaucratic reform to realize a clean, accountable and high-performance, effective and efficiently capable of providing quality public services, not run optimally for Sawahlunto scored 52.22 with the notation "CC" with a value of $50<$ values $>60$. The performance evaluation of the integrity of bureaucratic reform in Sawahlunto City was not run optimally based on a survey conducted showed the number 2.95 of a scale of $0-4$. So that after the evaluation resulted in some improvements to optimize the performance of the integrity of the bureaucracy reform in Sawahlunto. 
The evaluation aims to improve the performance of the service integrity bureaucratic reform in Sawahlunto carried out as suggestions and inputs were as follows:

1. Increase efforts to leaders actively involved in the implementation of the reform of the bureaucracy, especially the problem of integrity

2. Implement the bureaucratic reform program comprehensive and integrated manner, both the local governments and local device

3. Optimizing the role of a change agent with a target in the form of real change in each unit

4. Optimizing the HR management system including job competency standards, overall employee assessment and perfecting individual performance measures that refer to organizational performance, especially in Sawahlunto City

5. Develop and imposed a policy related to the strengthening of integrity that includes control of gratification, whistleblowing system, the handling of conflicts of interest, handling of public complaints and SPIP

6. Implemented a system of reward and punishment for those who implement the services and the provision of services to recipients compensate when the service received is not according to standards

7. Follow up surveys integrity of the position and the organization as well as the survey results public services and the perception of corruption.

8. Build integrity zone in the device area by regulation of the Minister PANRB No. 52 of 2014 on guidelines for the Development Zone integrity towards the area free from corruption and bureaucracy area clean and serve.

\section{References}

[1] E. Prasojo and T. Kurniawan, "Reformasi Birokrasi dan Good Governance: Kasus Best Practices dari Sejumlah Daerah di Indonesia," Symp. A Q. J. Mod. Foreign Lit., pp. 115, 2008.

[2] Z. . Frinces, Manajemen : Konsep Membangun Sukses. Yogyakarta: Mida Pustaka, 2008.

[3] Sedarmayanti, Reformasi administrasi publik, reformasi birokrasi, dan kepemimpinan masa depan: mewujudkan pelayanan prima dan kepemerintahan yang baik. Bandung: Refika Aditama, 2009.

[4] Yusriadi and Misnawati, "Reformasi Birokrasi dalam Pelayanan Publik (Studi Pelayanan Terpadu Satu Pintu),” J. Ilm. Ilmu Adm. Publik, vol. 7, pp. 99-108, 2017.

[5] G. Endro, "Menyelisik Makna Integritas dan Pertentangannya dengan Korupsi," $J$. Integritas Komisi Pemberantasan Korupsi, vol. 3, 2017.

[6] Aristotle, Ethica Nichomachea. Dalam The Basic Works of Aristotle, terj. W.D. Ross, ed. Richard McKeon. New York: Modern Library, 2001.

[7] B. Buchan, "Changing Contours of Corruption in Western Political Thought, c. 1200 1700," Corrupt. Expand. Focus, no. October, pp. 1-23, 2012, doi: 10.22459/cef.09.2012.05.

[8] J. P. Euben, “Corruption." Dalam Political Innovation and Conceptual Change, ed. Terence Ball, James Farr dan Russell L. Hanson. New York: Cambridge Univ. Press, 1989. 
[9] A. C. W. W. A. B. J. S. Hobbes; Leviathan, or, The matter, forme, \& power of a commonwealth ecclesiasticall and civill. London: Printed [by William Wilson] for Andrew Crooke, at the Green Dragon in St. Paul's Church-yard, 1651.

[10] L. Poltak, Reformasi Pelayanan Publik. Jakarta: Bumi Aksara, 2011.

[11] R. Surbakti, Memahami Ilmu Politik. Jakarta: Gramedia Pustaka Utama, 2010.

[12] O. Larasati, "MANAJEMEN PERUBAHAN DALAM REFORMASI BIROKRASI MENUJU INFORMATION TECHNOLOGY (IT)," J. Mitra Manaj., vol. 2, no. 4, pp. 273-285, 2018.

[13] E. A. dan W. K. Purwanto, Birokrasi Publik dalam Sistem Politik Semi-Parlementer. Yogyakarta: Gava Media, 2005.

[14] J. Pope, Strategi Memberantas Korupsi, Elemen Sistem Integritas Nasional. Jakarta: Yayasan Obor Indonesia, 2003.

[15] M. Albrow, Birokrasi (terjemahan). Yogyakarta: Tiara Wacana, 2005.

[16] I. Tanjung, "Kearifan Lokal dan Pemberantasan Korupsi dalam Birokrasi," MIMBAR, J. Sos. dan Pembang., vol. 29, no. 1, p. 101, 2013, doi: 10.29313/mimbar.v29i1.375.

[17] A. Dwiyanto, Reformasi Birokrasi Publik di Indonesia. Yogyakarta: Pusat Studi Kependudukan dan Kebijakan UGM, 2002.

[18] M. Toha, Government Bureaucracy and the Power in Indonesia (Birokrasi Pemerintah dan Kekuasaan di Indonesia). Yogyakarta: Matapena Institute, 2012.

[19] M. Horhoruw, T. G. Karippacheril, W. Sutiyono, and T. Thomas, "Transforming the Public Sector in Indonesia: Delivering Total Reformasi," World Bank Publ., no. March, pp. 1-14, 2012.

[20] D. Girindrawardana, "Public Services Reform in Indonesia," 2002.

[21] M. Pippidi, "Index of Public Integrity," Integrity Index, 2019. [Online]. Available: https://integrity-index.org/. [Accessed: 13-Feb-2020].

[22] A. Cordella and N. Tempini, "E-government and organizational change: Reappraising the role of ICT and bureaucracy in public service delivery," Gov. Inf. Q., vol. 32, no. 3, pp. 279-286, 2015, doi: 10.1016/j.giq.2015.03.005.

[23] Ahmad Amins, Manajemen Kinerja Pemerintah Daerah. Yogyakarta: Jaksbang pressindo, 2009.

[24] F. Masitah, "FACTOR ANALYSIS - EXTERNAL FACTORS AFFECTING THE FINANCING PRODUCTS (MURABAHAH AND MUDHARABAH) CASE STUDY IN BANK MUAMALAT INDONESIA TBK," Univ. Gunadarma, vol. 3, 2012.

[25] B. Blasi, "Peace journalism and the news production process," Confl. Commun. Online, vol. 3, no. 1, pp. 1-12, 2004.

[26] W. M. Isaac, Stephen., Handbook in research and evaluation. Sandiego: Edits Publisher, 1993.

[27] D. Conyers, Perencanaan Sosial di Dunia Ketiga. Yogyakarta: UGM Press, 1991.

[28] \& W. M. Isaac, Stephen., Handbook in research and evaluation. Sandiego: Edits Publisher, 1991.

[29] Yuliana Kurniawati Dima, "Evaluasi Pelaksanaan dan Strategi Keberlanjutan Program Padat Karya Pangan," J. Ilm. Adm. Publik, vol. 2, no. 4, pp. 171-176, 2016.

[30] Rosmi and Syamsir. (2020). The Influence of Integrity and Work Experience on Employee Performance. International Journal of Research and Analytical Reviews (IJRAR) „ 7 (1). pp. 789-794. ISSN Online: 2348-1269, Print: 2349-5138.

[31] Tasi, Riri and Syamsir, S. (2020). The Influence of Integrity and Loyalty on Employee Performance. International Journal of Research and Analytical Reviews (IJRAR). March 2020, Volume 7, Issue 1. pp. 774-779. Retrived from 
http://www.ijrar.org/viewfull.php?p_id=IJRAR2001817;and http://repository.unp.ac.id/ id/eprint/27258.

[32] Febrina, Dita and Syamsir, S. (2020). The Influence of Integrity and Commitment Organizational on Employee Performance. International Journal of Research and Analytical Reviews (IJRAR). March 2020, Volume 7, Issue 1. pp. 799-805. Retrived from http://www.ijrar.org/viewfull.php?p_id=IJRAR2001822; and Error! Hyperlink reference not valid.

[33] Wahyuni, Rahma Sri and Syamsir, S. (2020). The Influence of Integrity and Human Resource Management towards Employee Performance. International Journal of Research and Analytical Reviews (IJRAR). March 2020, Volume 7, Issue 1. pp. 780-785. Retrived from http://www.ijrar.org/viewfull.php?p_id=IJRAR2001818; and http://repository. unp.ac.id/id/eprint/26939

[34] Jayanti, Nur Putri and Syamsir. (2019). The Influence of Integrity on Employee Performance in Koto Tangah Subdistrict Padang. Atlantis Press Advances in Economics, Business and Management Research Vol 125

[35] Yolanda, Nadya Meidisyah and Syamsir. (2020). The Effect of Integrity on the Performance of Civil Servants in the Regional Apparatus Organization (OPD) of the Padang City Service. Perspective Journal: Journal of Sociology and Education Studies Vol. 3 No. 1

[36] Salwa, Arfah, Yuwaldi Away and Mirza Tabrani. (2018). The Effect of Commitment, Integrity and Competence on Employee Performance and Its Impact on the Performance of the Aceh Election Independent Commission. Journal of Master of Management Vol. 2 No.1

[37] Wetik, Stanislaus Wembly. (2018). Analysis of the Influence of Commitment and Integrity on Performance Through Employee Competence at the Port Authority and Harbor Authority Office of the City of Manado. YUME Journal of Management Vol. 1 No.3 pp. 137-151.

[38] Aski. Mhd. (2020). The Influence of Work Ethic and Integrity on the Performance of Civil Servants in the Regional Apparatus Organization of Padang City. Jess Journal of Education and Social Science Vol. 4 No. 1

[39] Syamsir \& Embi, MA (2020). Integrity Development Trough PSM For Corruption Prevention Among Public Servant. International Journal Of Psychosocial Rehabilitation, 24 (08).

[40] S. Arikunto, Prosedur Penelitian Suatu Pendekatan Praktek. Jakarta: Rineka Cipta, 2010.

[41] J. W. Creswell, Penelitian Kualitataif dan Desain Riset: Memilih di antara Lima Pendekatan, Edisi Ke-3. Yogyakarta: Pustaka Pelajar, 2015.

[42] Sugiyono, Metode Penelitian Administrasi. Bandung: Alfa Beta, 2011.

[43] Hadi Sutarto, "Inilah 8 area perubahan reformasi birokrasi," 2018. [Online]. Available: https://ulm.ac.id/id/2018/12/09/inilah-8-area-perubahan-reformasi-birokrasi/. [Accessed: 28-Jan-2020].

[44] Y. Prastowo, Reformasi Birokrasi dan Persoalan Subjek Etis. Jakarta: Raih Asa Sukses, 2014.

[45] M. Jufri, "Reformasi Birokrasi Dalam Pelayanan Publik," 2019. [Online]. Available: https://bengkulu.kemenag.go.id/opini/313-reformasi-birokrasi-dalam-pelayanan-publik. [Accessed: 21-Jan-2020]. 
[46] Government of Indonesia, Act of The Republic of Indonesia No. 31 of 1999 on Corruption Eradication (KPK). 1999, pp. 1-30.

[47] F. Fukuyama, State-Building: Governance and World Order in the 21st Century. New York: Cornell University Press, 2004.

[48] J. S. T. Quah, "Controlling corruption in city-states: A comparative study of Hong Kong and Singapore," Crime, Law Soc. Chang., vol. 22, no. 4, pp. 391-414, 1994, doi: 10.1007/BF01302927.

[49] J. Pope and F. Vogl, "Making Anticorruption Agencies More Effective," Financ. Dev. (A Q. Mag. IMF ), vol. 37, no. 2, pp. 6-9, 2000.

[50] Y. K. Nanang T. Puspito, Marcella Elwina S., Indah Sri Utari, Pendidikan Anti-Korupsi Untuk Perguruan Tinggi, Cetakan 1. Jakarta: Kementerian Pendidikan dan Kebudayaan RI Direktorat Jenderal Pendidikan Tinggi Bagian Hukum Kepegawaian, 2011.

[51] Elizabeth Ashford, "Utilitarianism, Integrity, and Partiality," J. Philos., vol. 39, pp. 421439, 2000, doi: 10.2307/2678423.

[52] S. van Hooft, "Integrity and the Fragile Self," Australas. J. Philos., vol. 81, no. 3, pp. 451-453, 2003, doi: 10.1080/713659695.

[53] Maman Sudiaman, "Korupsi dan Integritas," Republika, 2017. [Online]. Available: https://www.republika.co.id/berita/kolom/resonansi/17/03/30/onkz36319-korupsi-danintegritas. [Accessed: 19-Jan-2020].

[54] G. Endro, "Menyelisik Makna Integritas Dan Pertentangannya Dengan Korupsi," Anti Coruption Clearing House, 2017. [Online]. Available: https://acch.kpk.go.id/id/artikel/riset-publik/menyelisik-makna-integritas-danpertentangannya-dengan-korupsi. [Accessed: 10-Feb-2020]. 